\title{
Scope of phytotherapeutics in targeting ACE2 mediated Host-Viral Interface of SARS-CoV2 that causes COVID-19
}

\section{D.Sivaraman ${ }^{1,2}$, P.S.Pradeep ${ }^{1}$}

\begin{abstract}
Affiliations
${ }^{1}$ Centre for Laboratory Animal Technology and Research, Sathyabama Institute of Science and Technology, Jeppiaar Nagar, Chennai - 600 119, Tamil Nadu, India.

2 School of Pharmacy, Sathyabama Institute of Science and Technology, Jeppiaar Nagar, Chennai - 600 119, Tamil Nadu, India.

Corresponding Author : : D.Sivaraman

E-mail : sivaramand83@gmail.com

Telephone : :91-9841575334

Corresponding Address : : Sathyabama Institute of Science and Technology, Jeppiaar Nagar, ABSTRACT Rajiv Gandhi road, Chennai - 600 119, Tamil Nadu, India.
\end{abstract}

Severe acute respiratory syndrome coronavirus (SARS-CoV-2) that cause COVID-19 becomes a global threat and spread its pandemicity across the boundaries. Recent demography issued by WHO forecasting the severity of disease prevalence in more than 200 countries resulted in 16,96,588 laboratory confirmed cases excluding 1,05,952 deaths as on 12 April 2020. Countries like USA $(4,92,881)$, Italy $(1,52,271)$, Spain $(1,61,852)$, Germany $(1,20,479)$ are struggling hard to flatten their epidemic curve of COVID-19. Dynamic strategies are of utmost important in order to manage the crucial spread of SARS-CoV-2. Drug of herbal origin may offer reliable therapeutic opportunity in controlling widespread transmission. It was evident from the scientific outcomes that SARS-CoV2 gains access in to the host cell through angiotensin-converting enzyme 2 (ACE2) receptors. Hence drugs that reveals potential binding affinity with core amino acid of ACE-2 may expected to interfere the host-viral interaction. In our present investigation 28 lead molecules from well documented medicinal herbs were subjected to molecular docking analysis targeting ACE2 receptor and their potential of impeding host-viral interface were evaluated. Results of computational analysis signifies that out of 28 ligands nearly 11 bioactive lead molecules exhibit potential binding affinity of about $100 \%$ with the target amino acid residue (31 Lys and 353 Lys).

Key words: SARS-CoV-2, COVID-19, ACE2 receptor, Medicinal plants, Bioactive lead molecules. 


\section{Introduction}

In the scale of nomenclature coronaviruses belong to order Nidovirales, family Coronaviridae, in which SARS-CoV-2 categorized as betacoronavirus, with RNA genomic density of 29,891 nucleotides in size, encoding 9860 amino acids ${ }^{1}$. Novel coronal virus identified with presence of four major structural glycoproteins (spike(S), membrane $(\mathrm{M})$, nucleocapsid $(\mathrm{N})$ and envelope $(\mathrm{E})$ ) on its structural morphology ${ }^{2}$. It is well known that SARS-CoV-2 virus exerts its pathogenicity by binding with the Angiotensin-converting enzyme 2 (ACE2) receptor ${ }^{3,4}$.

ACE2 belongs to type I transmembrane metallocarboxypeptidase enzyme widely expressed in variety of cell, angiotensin II considered to be an endogenous substrate for ACE2 ${ }^{5}$ additionally this receptor is being recognized as binding site for novel corona virus for its pathogenesis. This grabs the attention of researcher globally to focus more on the architecture and morphology of this enzyme for possible identification of leads to exerts if affinity. Increased affinity of the lead compounds with that of the ACE2 keeps the enzyme more occupied and less available for viral interactions,

Medicinal herbs contribute to the benefit of the mankind since several centuries. Most significant pharmacophores of the existing drugs are derived from the herbal origin. Versatile functional group and side chain moieties synergies the affinity of receptor binding and thereby offers expected pharmacological activity ${ }^{6-9}$. On folklore basis metabolites from numerous herbs are known for managing diseases and disorders around the globe

Traditional medicines like Nilavembu Kudineer and Kaba Sura Kudineer reasonable occupies the prescriptions of the indian medicine practitioners in the clinical management of viral infections, perhaps these two formulations are officially recommending by the government authorities for afore mentioned cause. The rationale behind selection of these Indian medicines is because of its claim in management of epidemic viral infection and also due to the existence of combinatorial makeup of their relative therapeutics components. Formulation Nilavembu Kudineer (NVK) majorly consist of Andrographis Paniculata, Plectranthus Vettiveroides, Vetiveria Zizanioides, Zingiber Officinale, Piper Nigrum, Cyperus Rotundus, Santalum Album, Trichosanthes Cucumerina and Mollugo Cerviana ${ }^{10,11}$. Other formulation Kaba Sura Kudineer (KSK) comprises of fifteen herbs such as Zingiber Officinale, Piper longum, Sysygium aromaticum, Tragia involucrata, Anacyclus pyrethrum, Hygrophila auriculata, Terminalia chebula, Justicia adhatoda, Plectranthus amboinicus ,Saussurea costus, Tinospora sinensis ,Premna herbacea, Andrographis Paniculata, Cissampelos pariera and Cyperus Rotundus ${ }^{12-14}$.

In our present investigation 28 bioactive leads (6-Shogaol, 6-Gingerol, Beta Sitosterol, Piperidine, Apigenin, Piperine, Quercetin, Chlorogenic Acid, Beta-Pinene, Alpha-Bisabolol 
,Andrographolide, Bharangin, Carvacrol, Cissamine, Costunolide, Cucurbitacin B, Gallic acid, Linoleic acid, Pellitorine, Rutin, Santalic acid, Spathulenol, Vasicine, Vetiverol, Cynaropicrin, Eugenol, Thymol and Vitexin) retrieved based on the literature search on the herbal ingredients present in both these traditional siddha medicines (NVK \& KSK) were subjected to the In-Silico evaluation in targeting active site of the ACE2 receptor that mediates the host- viral interface.

\section{Materials and Methods}

\subsection{Protein-ligand docking}

Computational molecular investigation was performed using Auto Dock version 4 which predicts interaction binding affinity between selected therapeutic lead with that of the protein target (SARS$\mathrm{CoV}$ tagged - Angiotensin-converting enzyme 2 (ACE2)- PDB- 2AJF.

\subsection{Protein preparation}

Three dimensional (3D) structure of SARS-CoV bounded ACE2 with protein data bank (PDB)-2AJF (Figure 1) retrieved from Research Collaboratory for Structural Bioinformatics (RCSB). Protein structure were cleaned by removing the existing lead components, water molecules cleaved, Gasteiger charges computed with inclusion of polar hydrogens, merging of non-polar and rotatable bonds were defined using Auto Dock $4^{15,16}$.

\subsection{Active site prediciton on the target protein}

Biologically active amino acid residues which are primary involved in executing the viral host interface was predicted using Ramachandran plot indicating localization of the residues on the A chain of the target enzyme. Prediction by MolProbity server and also through literature survey. Ramachandran plot signifies the sequential paradigm of 1542 residues which are present in refinement carried out in

REFMAC 5.2.0019. $\mathrm{R}=0.218$; $\mathrm{R}$ free $=0.275$, and the structure was solved at $2.90 \AA$ resolution as shown in Figure 2.

\subsection{Ligand model preparation}

Structures of the bioactive lead compounds such as 6-Shogaol, 6-Gingerol, Beta Sitosterol, Piperidine, Apigenin, Piperine, Quercetin, Chlorogenic Acid, Beta-Pinene, Alpha-Bisabolol ,Andrographolide, Bharangin, Carvacrol, Cissamine, Costunolide, Cucurbitacin B, Gallic acid, Linoleic acid, Pellitorine, Rutin, Santalic acid, Spathulenol, Vasicine, Vetiverol, Cynaropicrin, Eugenol, Thymol and Vitexin subjected to docking investigation were outlined using ChemDraw sketch software and converted from two dimension (2D) to 3D structures. Figure 3 and 4 Summarizing $2 \mathrm{D}$ and 3D structure of Bio-active therapeutic ligand subjected to molecular docking Investigation against SARS$\mathrm{CoV}$ tagged - Angiotensin-converting enzyme 2 - PDB- 2AJF. 


\subsection{Docking simulations}

3D componential structure of lead molecules and protein were docked using AutoDock analytical tool version 4. Affinity (grid) maps of $\times \times \AA$ grid points and $0.375 \AA$ spacing were generated using the Autogrid program ${ }^{17}$. AutoDock parameter set- and distance-dependent dielectric functions were used in the calculation of the van der Waals and the electrostatic terms, respectively. Docking simulations were performed using the programmed algorithm inbuilt with pre automation in the software. Initial position, orientation, and torsions of the ligand molecules were set randomly. All rotatable torsions were released during docking. Each docking experiment was derived from 2 different runs that were set to terminate after a maximum of 250000 energy evaluations. The population size was set to 150 . During the search, a translational step of $0.2 \AA$, and quaternion and torsion steps of 5 were applied.

\section{Results and Discussion}

ACE2 receptors becomes primary target for SARS-CoV-2 to exert its pathogenicity in the affected individuals ${ }^{18,19}$. SARS-CoV-ACE2 receptors possess two promising active biding sites that residue located primly on Lys 31 and another hotspot is Lys 353. The active site Lys 31 hierarchically bridged between amino acid Lys 31 - Glu 35. Similarly, site Lys 353 bridged between ASP 38 - Lys 353. Series of amino acids (Leu455, Phe486, Ser494) lying on binding motif of SARS-CoV-2 primary mediates the biding paradigm of virus with that of the two primary hotspots (Lys 31 and Lys 353) that resides on the ACE2 receptor ${ }^{20,21}$. The amino terminal peptides of ACE2 glycoprotein tailed outwards targeted by receptor binding domain of SARS-CoV-2.

Results of computational analysis signifies that out of 28 ligands retrieved from two Indian medicines nearly 11 bioactive lead molecules that includes Rutin, Pellitorine, Cynaropicrin, Andrographolide, Linoleic acid, Cucurbitacin B,Vitexin, 6-Gingerol ,Beta Sitosterol, Apigenin and Quercetin exhibit potential binding affinity of about 100\% with the target amino acid residue (31 Lys and 353 Lys). Other seven compounds (Eugenol, Gallic acid, Thymol, Costunolide, Bharangin, 6Shogaol and Piperine) contributes binding affinity only with 31 Lys, whereas four compounds (Carvacrol, Santalic acid, Piperidine and Chlorogenic acid) bound only with 353 Lys. Remaining five compounds includes Vasicine, Beta-Pinene, Spathulenol, Vetiverol and Alpha-Bisabolol fails to offer expected affinity on both the amino acid present in the target site. Results of docking score along with amino acid residual interactions were summarized in Table 1 and Table 2. 


\section{Conclusion}

Present investigation only explorate the binding potential of the valuable leads with that of the active residues of ACE2 that involved in mediating the host viral interface. Hence in future systematic investigation at In-vitro, In-vivo and clinical level become highly essential to validate the efficacy of these lead molecules prior to the recommendation.

\section{Acknowledgements}

The Ministry of AYUSH (Ayurveda, Yoga \& Naturopathy, Unani, Siddha and Homoeopathy), Government of India, Indian Council of Medical Research (ICMR), Government of India, Chinese Association for Laboratory Animal Sciences (CALA), P.R.China.

\section{Author contributions}

Authors are equally involved in study design, simulation, data collection and compilation

\section{Competing interests}

The authors declare no competing interests.

\section{References}

1. Zhu N, Zhang D, Wang W, et al. A novel coronavirus from patients with pneumonia in China, 2019. N Engl J Med. 2020; 382: 727- 733.

2. Schoeman, D., Fielding, B.C. Coronavirus envelope protein: current knowledge. Virol J.2019; 16,69 .

3. Wrapp D, Wang N, Corbett KS, et al. Cryo-EM structure of the 2019-nCoV spike in the prefusion conformation. Science. 2020:eabb2507. https://doi.org/10.1126/science.abb2507

4. Zou L, Ruan F, Huang M, et al. SARS-CoV-2 viral load in upper respiratory specimens of infected patients. N Engl J Med. 2020:2001737. https://doi.org/10.1056/NEJMc2001737.

5. Vaibhav BP. Role of the ACE2/Angiotensin 1-7 axis of the Renin-Angiotensin System in Heart Failure. Circ Res. 2016; 118: 1313-1326.

6. Si-Yuan Pan. New Perspectives on How to Discover Drugs from Herbal Medicines: CAM's Outstanding Contribution to Modern Therapeutics. Evid Based Complement Alternat Med. 2013; 2013: 627375.

7. Atanas GA. Discovery and resupply of pharmacologically active plant-derived natural products: A review. Biotechnol Adv. 2015 Dec; 33(8): 1582-1614.

8. D.Sivaraman, N.Anbu, N.Kabilan, M.Pitchiah Kumar, P.Shanmugapriya , G.J.Christian. Review On Current Treatment Strategy In Alzheimer's Disease And Role Of Herbs In Treating Neurological Disorders. International journal of translational research in Indian medicine.2019;1(1):33-43.

9. D.Sivaraman, N.Anbu, N.Kabilan, M.Pitchiah Kumar, P.Shanmugapriya , G.J.Christian. Exploration of Anti-Urolithiasis Potential of Traditional Siddha formulations Amukkara Chooranam and Karisalai Karpam Chooranam by Struvite Crystal Growth Inhibition Assay. Pharmacognosy Journal.2019;11(4):683-688.

10. Jain J et al. Antiviral activity of ethanolic extract of Nilavembu Kudineer against dengue and chikungunya virus through in vitro evaluation. J Ayurveda Integr Med. 2019. DOI: 10.1016/j.jaim.2018.05.006. 
11. Anbarasu $\mathrm{K}$ et al. Antipyretic, anti-inflammatory and analgesic properties of nilavembu kudineer choornam: a classical preparation used in the treatment of chikungunya fever. Asian Pac J Trop Med. 2011;4:819-823.

12. Siddha perspective of managing swine flu with Kaba sura kudineer. https://www.nhp.gov.in/swine-flu_mtl (accessed on 30 March 2020)

13. Uthamarayan KS, Siddha Maruthuvanga churukkam, Directorate of Indian Medicine \& Homeopathy, Chennai- 106, 2006.

14. Murugesa Mudaliar KS. Siddha Materia Medica, Directorate of Indian Medicine \& Homeopathy, Chennai-106, 2013.

15. Huey R, Morris GM, Olson AJ, Goodsell DS .A semiempirical free energy force field with charge-based desolvation. J Comput Chem.2007;28:1145-1152.

16. Bikadi Z, Hazai E .Application of the PM6 semi-empirical method to modeling proteins enhances docking accuracy of AutoDock. J. Cheminf.2009; 1:1- 15.

17. Stefano F, Ruth H, Michael EP, Michel S, David SG, Arthur J. Olson. Computational proteinligand docking and virtual drug screening with the AutoDock suite. Nat Protoc, 2016; 11:90519.

18. Andersen KG, Rambaut A, Lipkin WI, Holmes EC, Garry RF. The proximal origin of SARSCoV-2. Nat Med (2020)1-3. doi:10.1038/s41591-020-0820-9.

19. Chen Y, Liu Q, Guo D. Emerging coronaviruses: Genome structure, replication, and pathogenesis. J. Med. Virol. 2020;92:418-423.

20. Li F, Li W, Farzan M, Harrison SC. Structural biology: Structure of SARS coronavirus spike receptor-binding domain complexed with receptor. Science; 2005;309:1864-1868. doi:10.1126/science.1116480.

21. Wan Y, Shang J, Graham R, Baric RS, Li F. Receptor recognition by novel coronavirus from Wuhan: An analysis based on decade-long structural studies of SARS. J Virol (2020) doi:10.1128/jvi.00127-20.

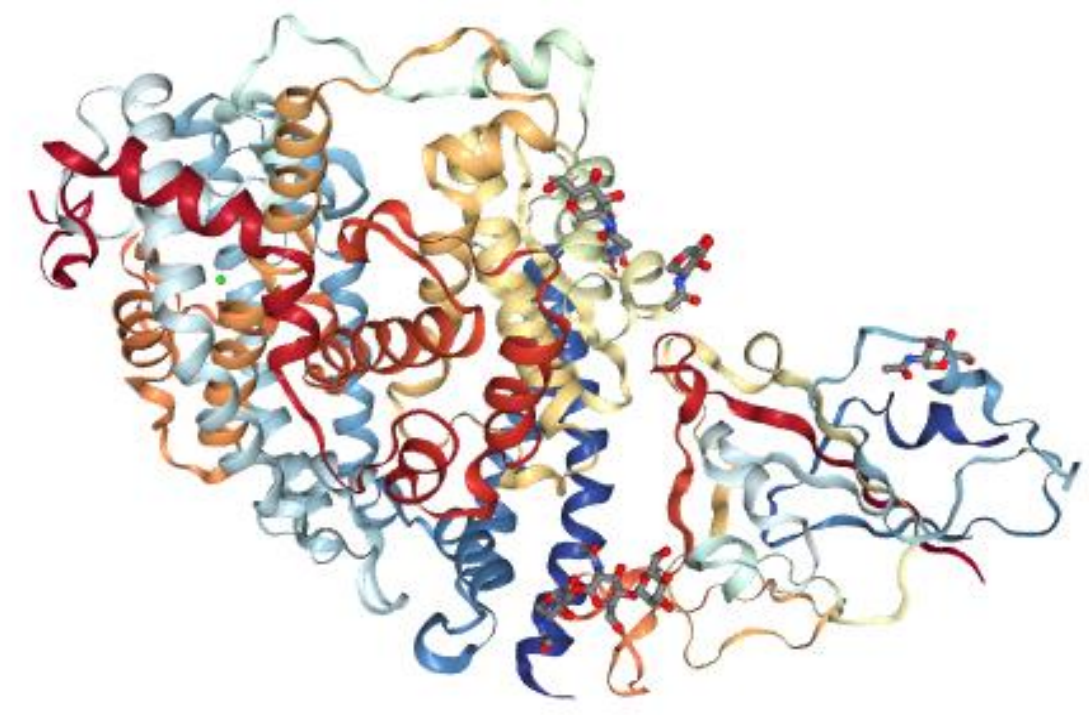

Figure 1. 3D structure of SARS-CoV attached with its cellular receptor, Angiotensinconverting enzyme 2 (ACE2)- (PDB)- 2AJF 

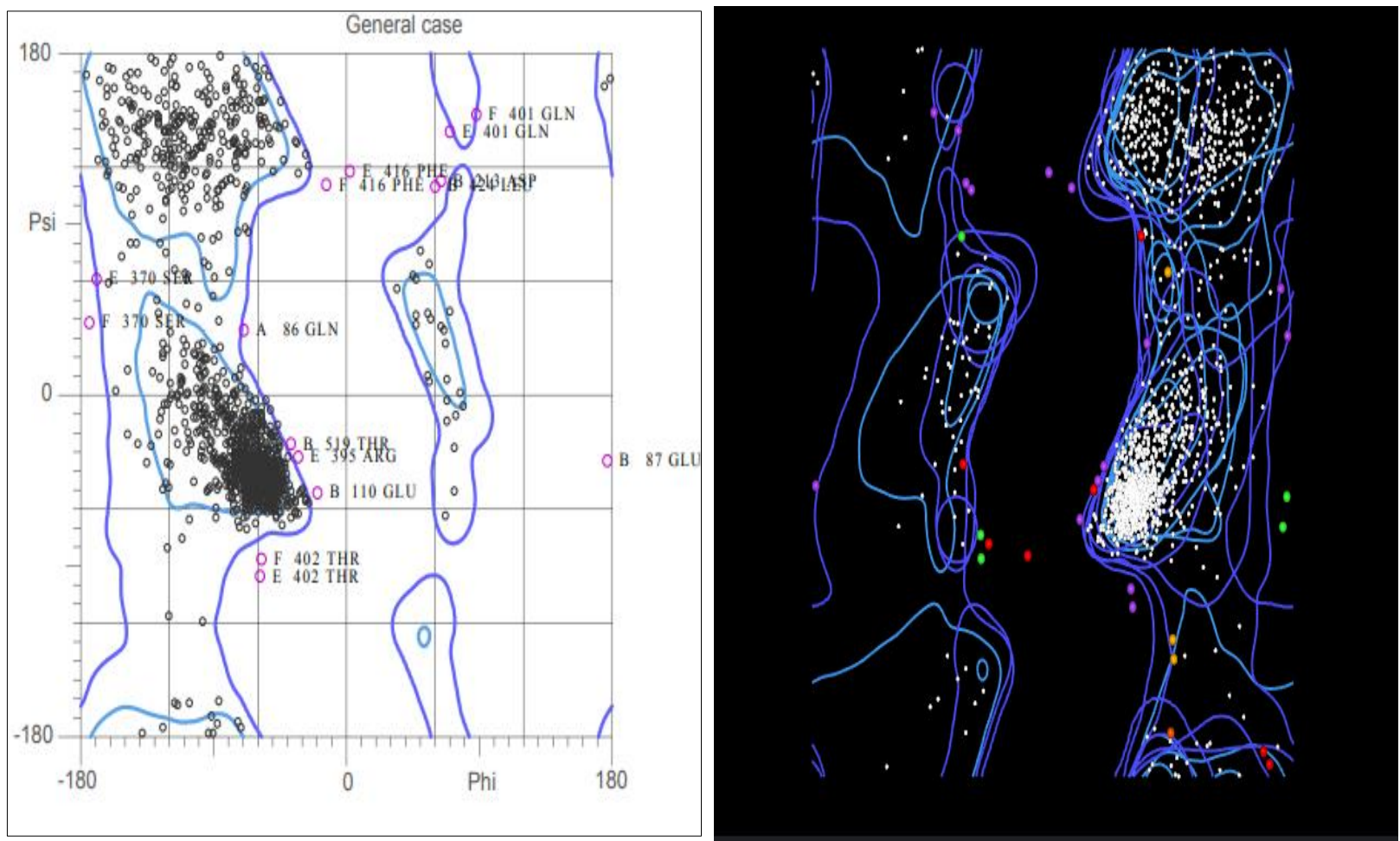

$\mathrm{R}=0.218$; Rfree $=0.275$, A total of 1542 residues are present., Structure was solved at $2.90 \AA$ resolution, 81 hetero group(s) are present.

Figure 2. Ramachandran plot indicating amino acid resides in cluster of A- Chain Angiotensin-converting enzyme 2 (ACE2)- (PDB)- 2AJF

\begin{tabular}{cccccc}
\hline Chain & Res & High B & Ramachandran & Rotamer & C $\beta$ deviation \\
\hline A 31 & LYS & 96.1 & $\begin{array}{c}\text { Favored }(33.64 \%) \\
\text { General / -79.6,-38.6 }\end{array}$ & $\begin{array}{c}\text { Allowed }(0.4 \%) \text { tmmt } \\
\text { chi angles: } 182.4,268.9,291.4,139.7\end{array}$ & $0.00 \AA$
\end{tabular}

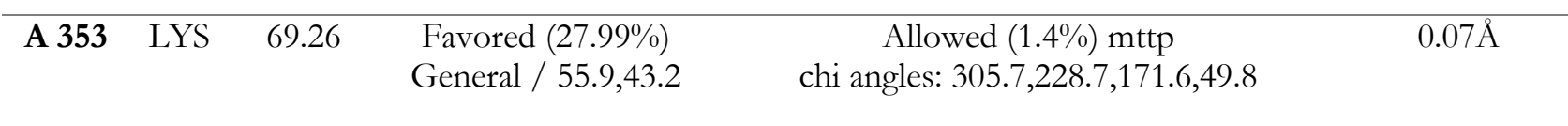


Table 1: Summarizing sequential binding behavior of phytotherapeutic lead molecules with that of the target Amino acid residues at Angiotensin-converting enzyme 2 (ACE2)- (PDB)2AJF

\begin{tabular}{|c|c|c|c|c|c|c|c|c|c|c|c|}
\hline S.No & Molecule & $\begin{array}{l}\text { Docking } \\
\text { Score } \\
\text { (K cal/mol) }\end{array}$ & & & & Amino Aci & esidues & & & & \\
\hline 1 & m-Eugenol & -2.53 & 31 LYS & 34 HIS & $35 \mathrm{GLU}$ & 38 ASP & & & & & \\
\hline 2 & Rutin & -3.41 & 27 THR & 31 LYS & $34 \mathrm{HIS}$ & $35 \mathrm{GLU}$ & 38 ASP & 353 LYS & & & \\
\hline 3 & Pellitorine & -3.4 & 31 LYS & 34 HIS & $37 \mathrm{GLU}$ & 38 ASP & 353 LYS & & & & \\
\hline 4 & Gallic acid & -2.02 & 31 LYS & 34 HIS & $35 \mathrm{GLU}$ & & & & & & \\
\hline 5 & Vasicine & -6.21 & $40 \mathrm{PHE}$ & 350 ASP & $390 \mathrm{PHE}$ & 393 ARG & 394 ASN & & & & \\
\hline 6 & p-Thymol & -2.75 & 31 LYS & $34 \mathrm{HIS}$ & $35 \mathrm{GLU}$ & & & & & & \\
\hline 7 & Carvacrol & -3.31 & $33 \mathrm{ASN}$ & $34 \mathrm{HIS}$ & $37 \mathrm{GLU}$ & 38 ASP & 353 LYS & 390 PHE & $\begin{array}{l}393 \\
\text { ARG }\end{array}$ & & \\
\hline 8 & Costunolide & -4.00 & 27 THR & 30 ASP & 31 LYS & $34 \mathrm{HIS}$ & & & & & \\
\hline 9 & Cynaropicrin & -3.06 & 31 LYS & $34 \mathrm{HIS}$ & $35 \mathrm{GLU}$ & 38 ASP & 353 LYS & & & & \\
\hline 10 & Bharangin & -4.36 & 31 LYS & $34 \mathrm{HIS}$ & $35 \mathrm{GLU}$ & 38 ASP & & & & & \\
\hline 11 & Andrographolide & -4.53 & 31 LYS & $34 \mathrm{HIS}$ & $35 \mathrm{GLU}$ & $37 \mathrm{GLU}$ & 38 ASP & 353 LYS & & & \\
\hline 12 & Cissamine & -4.77 & $34 \mathrm{HIS}$ & $37 \mathrm{GLU}$ & 353 LYS & 389 PRO & $\begin{array}{l}393 \\
\text { ARG }\end{array}$ & & & & \\
\hline 13 & Beta-Pinene & -5.22 & $37 \mathrm{GLU}$ & $40 \mathrm{PHE}$ & 350 ASP & $390 \mathrm{PHE}$ & $\begin{array}{l}393 \\
\text { ARG }\end{array}$ & & & & \\
\hline 14 & Spathulenol & -4.98 & 30 ASP & $33 \mathrm{ASN}$ & $34 \mathrm{HIS}$ & $37 \mathrm{GLU}$ & 390 PHE & $\begin{array}{l}393 \\
\text { ARG }\end{array}$ & & & \\
\hline 15 & Vetiverol & -4.96 & 30 ASP & $33 \mathrm{ASN}$ & $34 \mathrm{HIS}$ & $37 \mathrm{GLU}$ & 389 PRO & $\begin{array}{l}393 \\
\text { ARG }\end{array}$ & & & \\
\hline 16 & Linoleic acid & -2.07 & 30 ASP & 31 LYS & $34 \mathrm{HIS}$ & $37 \mathrm{GLU}$ & 38 ASP & 353 LYS & & & \\
\hline 17 & Santalic acid & -3.41 & $33 \mathrm{ASN}$ & $34 \mathrm{HIS}$ & $37 \mathrm{GLU}$ & 353 LYS & $\begin{array}{l}393 \\
\text { ARG }\end{array}$ & & & & \\
\hline 18 & Cucurbitacin B & -5.36 & 30 ASP & 31 LYS & $34 \mathrm{HIS}$ & $37 \mathrm{GLU}$ & 38 ASP & 353 LYS & & & \\
\hline 19 & Vitexin & -5.71 & 31 LYS & $34 \mathrm{HIS}$ & $35 \mathrm{GLU}$ & 37 GLU & 38 ASP & 42 GLN & $\begin{array}{l}353 \\
\text { LYS }\end{array}$ & & \\
\hline 20 & Alpha-Bisabolol & -5.69 & $40 \mathrm{PHE}$ & 350 ASP & $390 \mathrm{PHE}$ & $391 \mathrm{LEU}$ & $\begin{array}{l}393 \\
\text { ARG }\end{array}$ & 394 ASN & $\begin{array}{l}562 \\
\text { LYS } \\
\end{array}$ & & \\
\hline 21 & 6-Shogaol & -3.33 & 31 LYS & 34 HIS & $35 \mathrm{GLU}$ & 38 ASP & $39 \mathrm{LEU}$ & 42 GLN & & & \\
\hline 22 & 6-Gingerol & -3.49 & 31 LYS & $34 \mathrm{HIS}$ & $35 \mathrm{GLU}$ & $37 \mathrm{GLU}$ & $38 \mathrm{ASP}$ & 353 LYS & & & \\
\hline 23 & Beta Sitosterol & -4.88 & 27 THR & 30 ASP & 31 LYS & 34 HIS & $35 \mathrm{GLU}$ & 38 ASP & $\begin{array}{l}353 \\
\text { LYS }\end{array}$ & & \\
\hline 24 & Piperidine & -4.31 & 30 ASP & $33 \mathrm{ASN}$ & $34 \mathrm{HIS}$ & $35 \mathrm{GLU}$ & $37 \mathrm{GLU}$ & 38 ASP & $\begin{array}{l}353 \\
\text { LYS }\end{array}$ & $\begin{array}{l}389 \\
\text { PRO }\end{array}$ & $\begin{array}{l}393 \\
\text { ARG }\end{array}$ \\
\hline 25 & Apigenin & -3.75 & 31 LYS & $34 \mathrm{HIS}$ & $35 \mathrm{GLU}$ & 38 ASP & 353 LYS & & & & \\
\hline 26 & Piperine & -4.1 & 31 LYS & $34 \mathrm{HIS}$ & $35 \mathrm{GLU}$ & 37 GLU & 38 ASP & & & & \\
\hline 27 & Quercetin & -4.11 & 31 LYS & 34 HIS & $35 \mathrm{GLU}$ & 38 ASP & 353 LYS & & & & \\
\hline 28 & $\begin{array}{l}\text { Chlorogenic } \\
\text { Acid }\end{array}$ & -2.15 & $37 \mathrm{GLU}$ & $35 \mathrm{GLU}$ & $37 \mathrm{GLU}$ & 38 ASP & 353 LYS & & & & \\
\hline
\end{tabular}


Figure 3: 2D structure of Bio-active therapeutic ligand subjected to molecular docking Investigation against angiotensin-converting enzyme 2 (ACE2)- 2AJF (PDB)
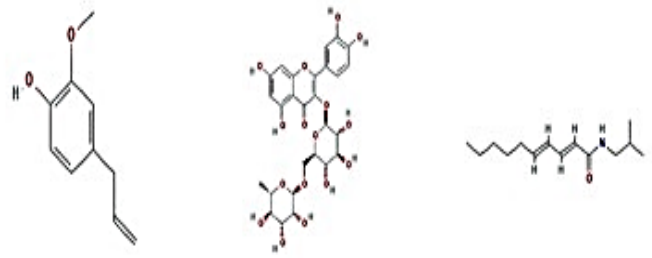

1

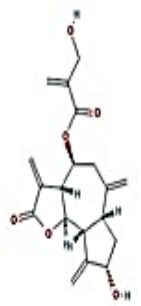

9
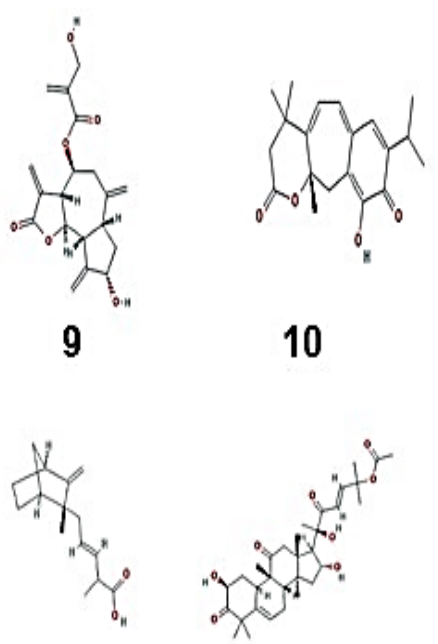

17

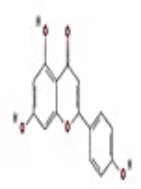

25
10

18

2
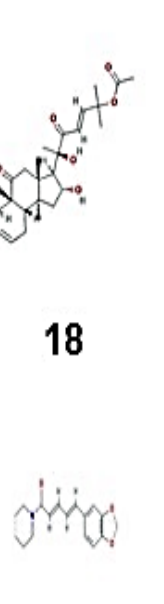

26

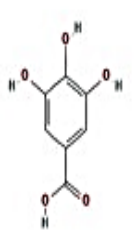

4

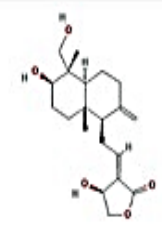

11

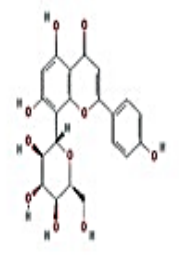

19

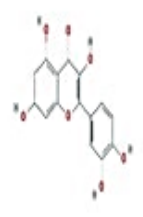

27<smiles>OC1CCN2Cc3ccccc3C=C12</smiles>

5

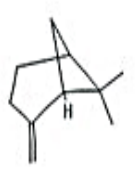

13

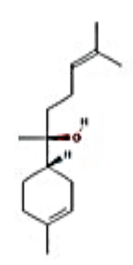

20

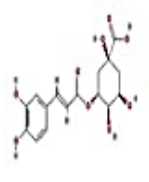

28

21<smiles>CC1CCC(C(C)C)C(C)C1</smiles>

6
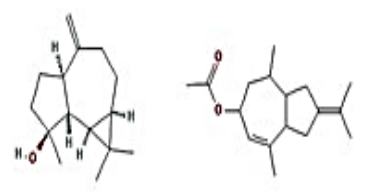

15<smiles>[Te][Te][Te]</smiles><smiles>[Te][Te]CI</smiles>

22

23
16

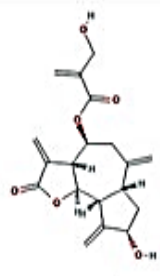

8

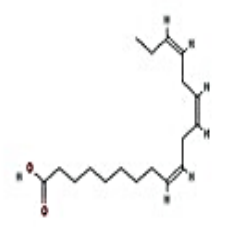<smiles>[Tl]C1CCCCC1</smiles>

24 
Figure 4: 3D structure of Bio-active therapeutic ligand subjected to molecular docking Investigation against angiotensin-converting enzyme 2 (ACE2)- 2AJF (PDB)

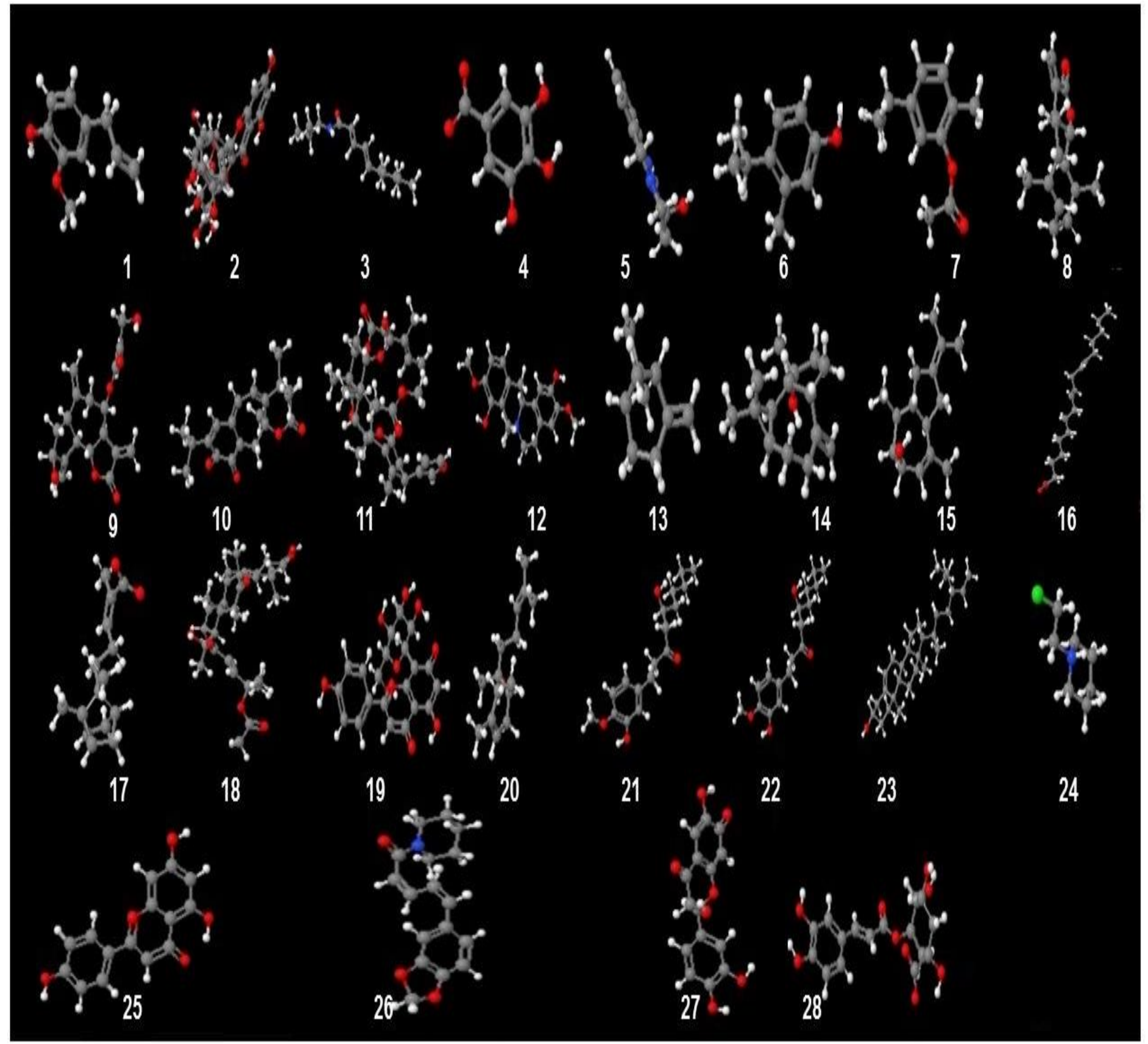


Table 2: Summarizing the docking score and representing the interaction analysis plot with best binding docking pose of phytochemicals from the potentials herbs against Angiotensinconverting enzyme 2 (ACE2)- (PDB)- 2AJF

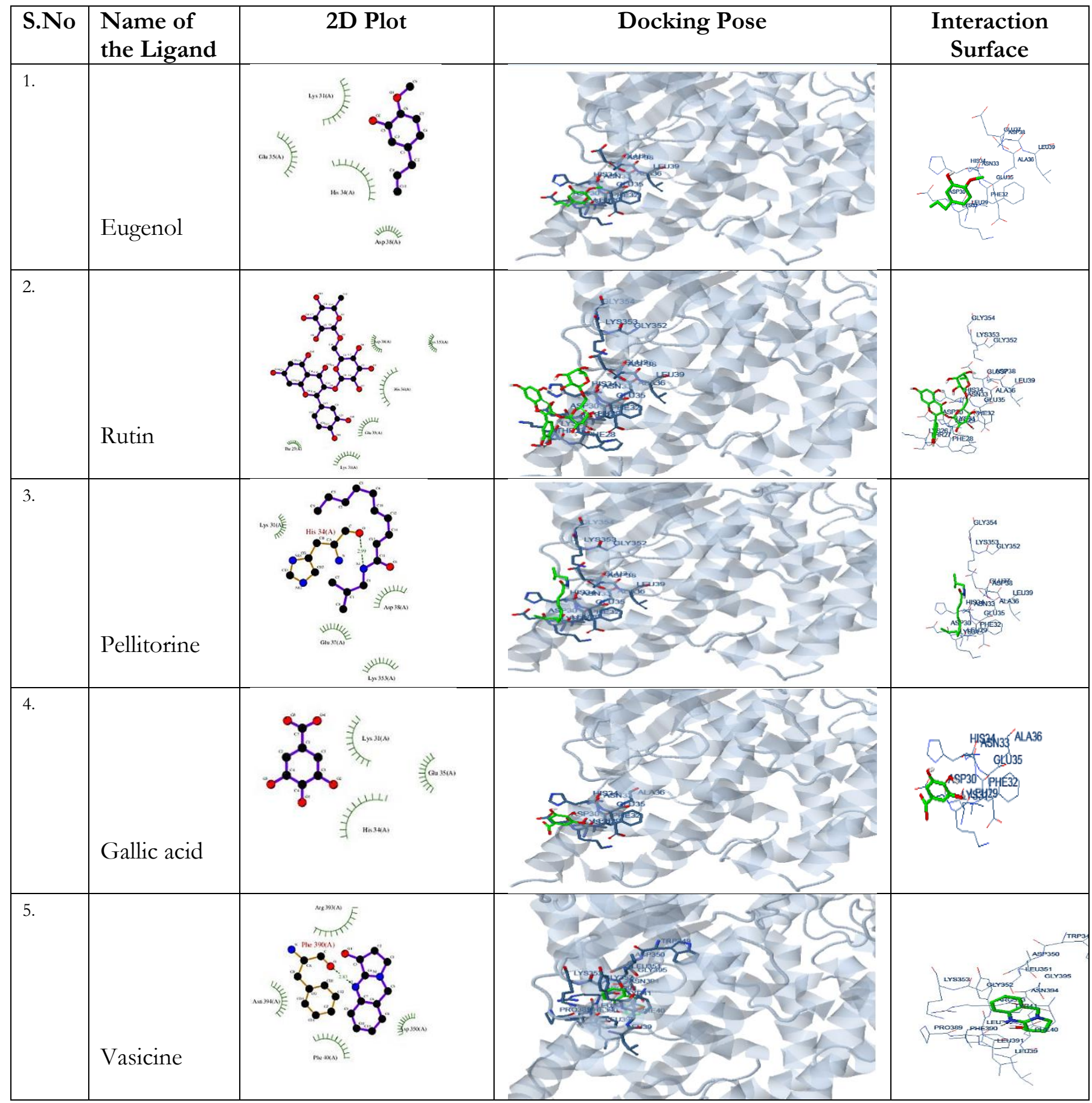




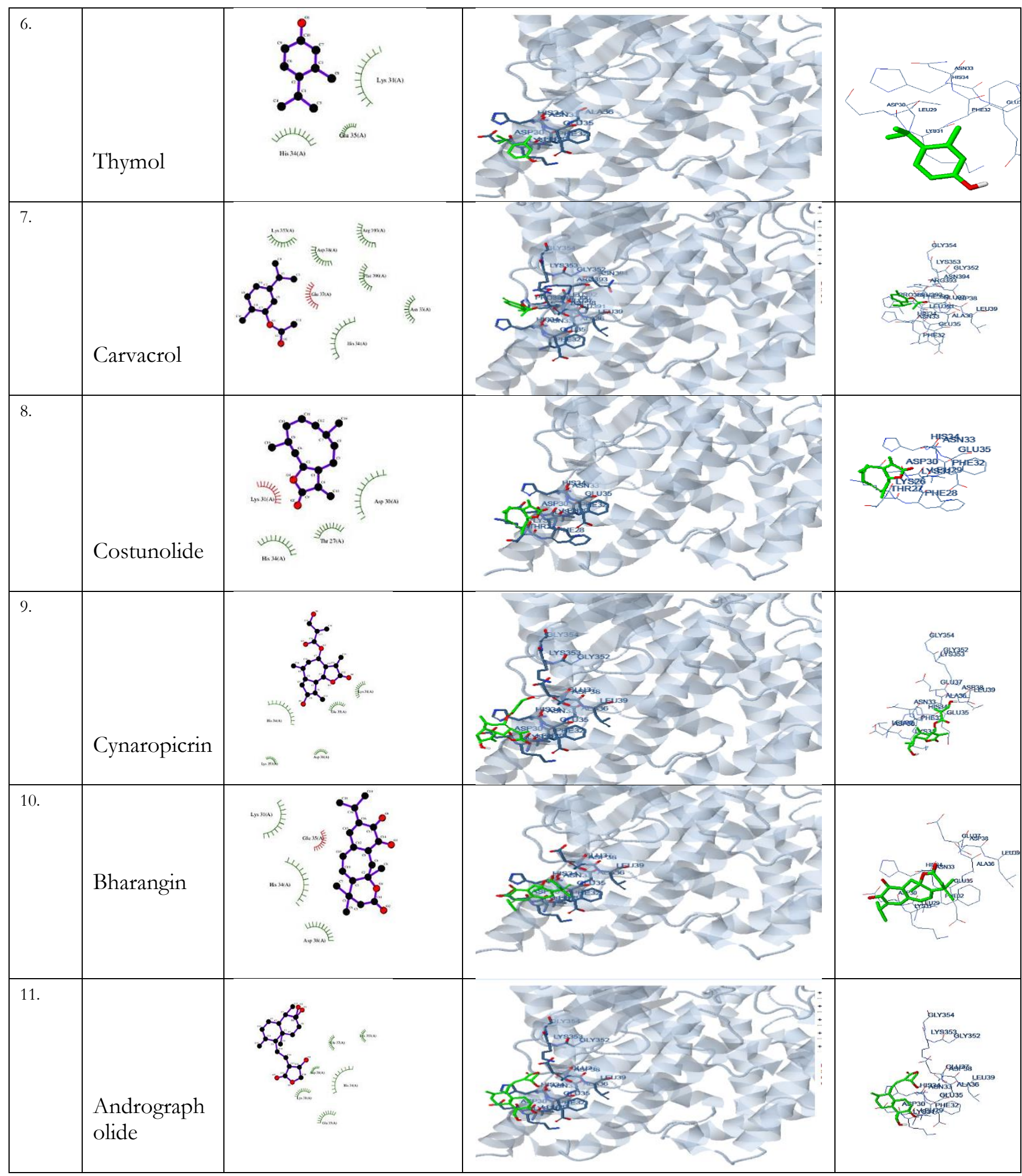




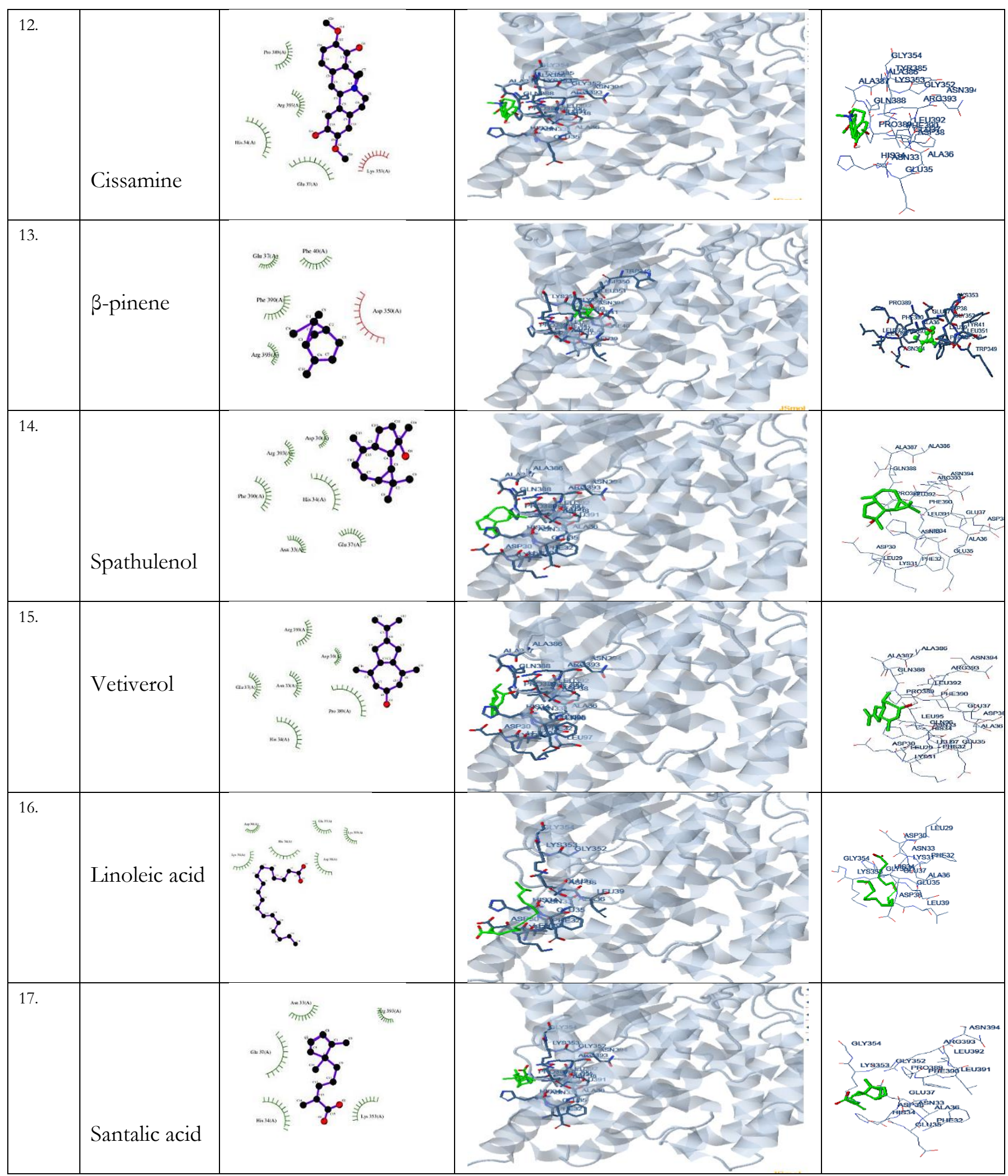




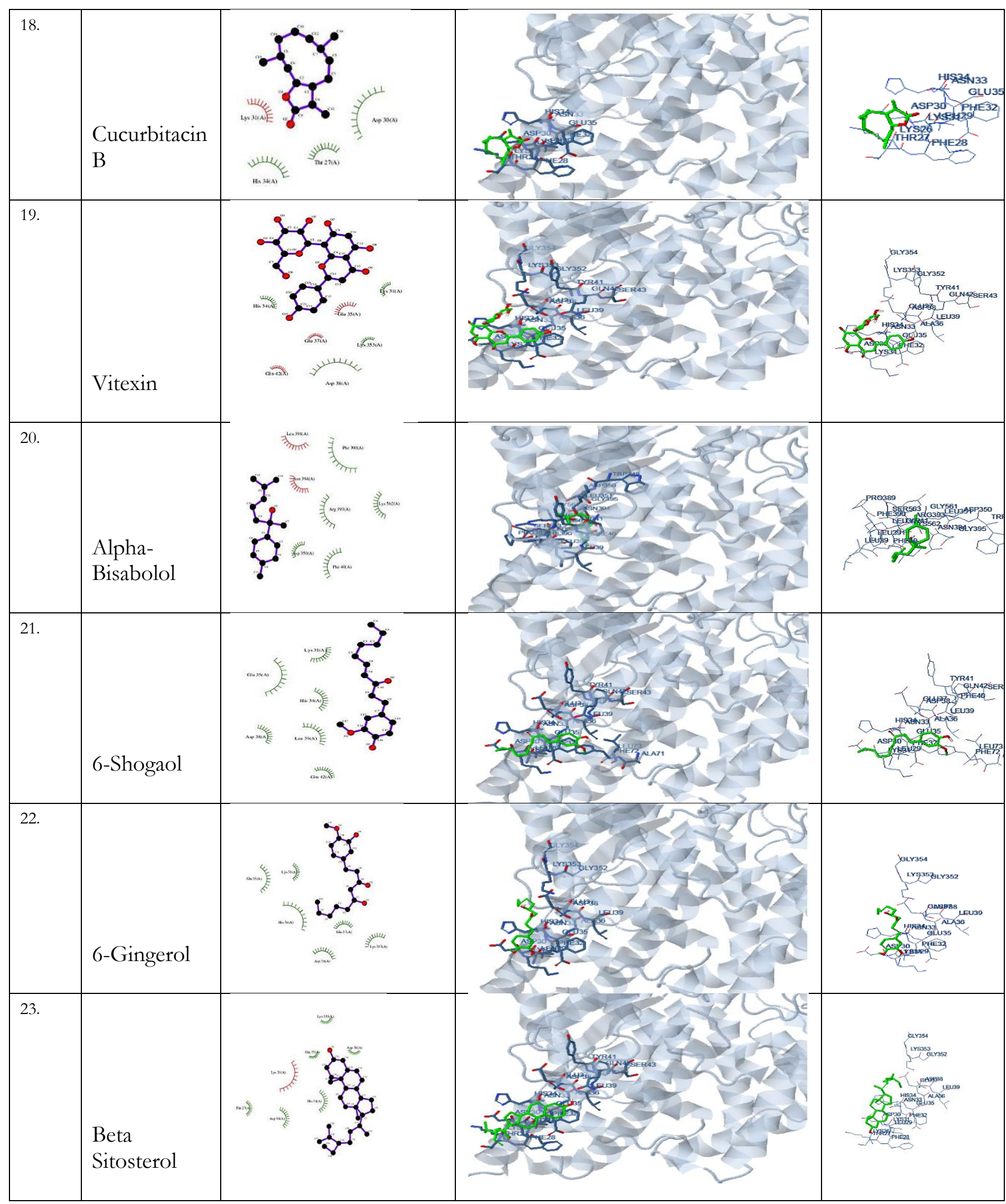




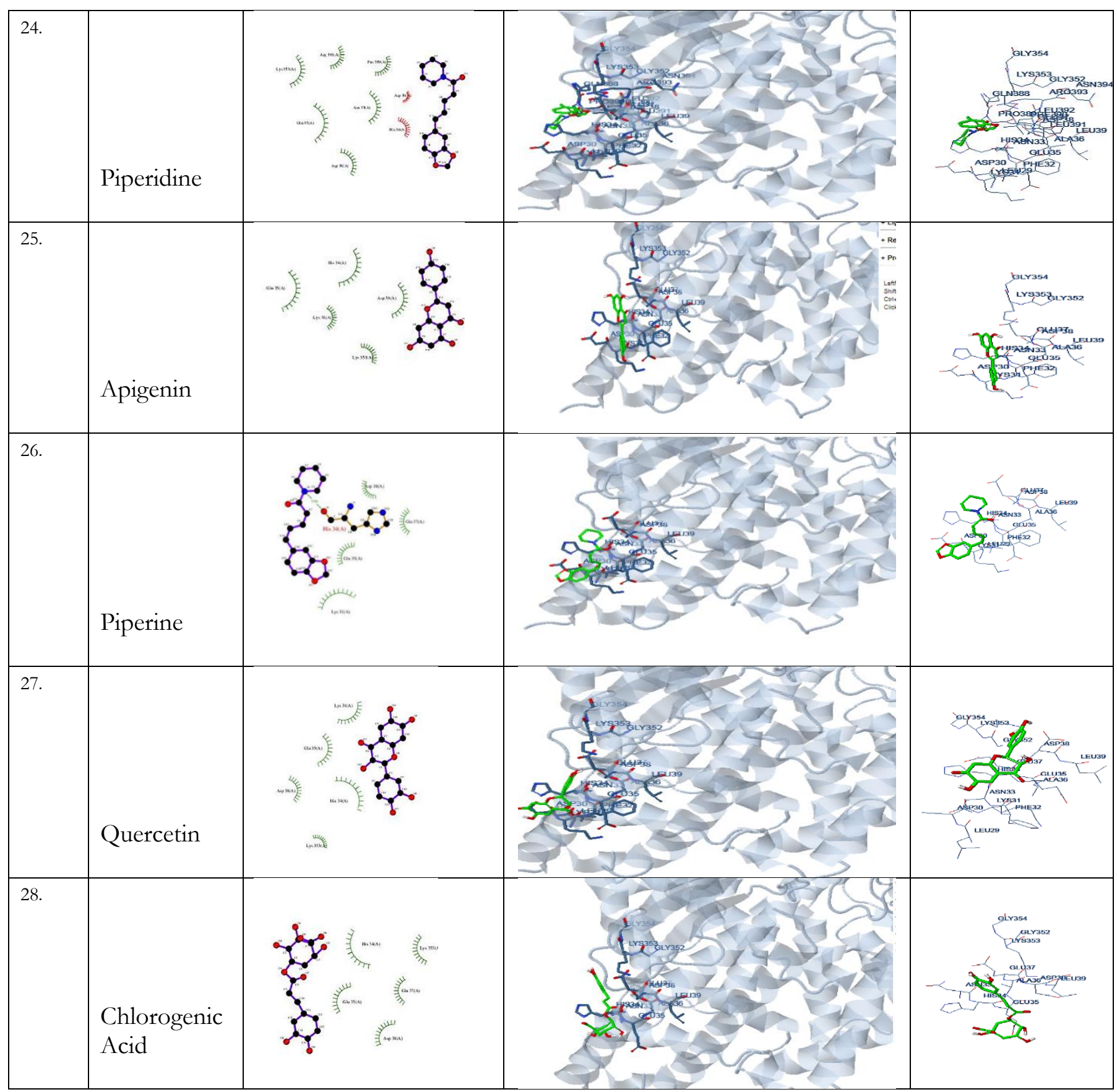

